\title{
Screening for tarmkreft virker
}

\author{
Screening for tarmkreft med fleksibel sigmoidoskopi reduserer fore- \\ komst og død av sykdommen, og for de fleste er én undersøkelse nok.
}

Opp mot 4000 personer rammes årlig av kreft i tykktarmen og endetarmen i Norge, og dødeligheten er på rundt $40 \%$. Screening med fleksibel sigmoidoskopi eller koloskopi kan både føre til at kreft oppdages tidligere og at kreft forebygges ved å fjerne adenomatøse polypper. Det er en utbredt oppfatning at personer som har fått fjernet adenomatøse polypper har høy risiko for senere å utvikle kreft, og disse personene kontrolleres derfor hyppig med nye koloskopier.

Mitt doktorgradsarbeid bygger på en randomisert kontrollert studie med over 100000 kvinner og menn i alderen 50-64 år. Vi fant at gruppen som ble tilbudt screening med fleksibel sigmoidoskopi hadde
$20 \%$ lavere forekomst og $27 \%$ færre dødsfall av tarmkreft sammenliknet med kontrollgruppen som ikke ble tilbudt screening. I en kohortstudie med over 40000 deltakere fant vi at personer som har fått fjernet adenomatøse polypper fra tarmen ikke har økt risiko for å dø av tarmkreft sammenliknet med resten av den norske befolkningen.

Resultatene indikerer at én screeningundersøkelse for tarmkreft i 50-60 års alder kan være hensiktsmessig, og for de aller fleste behøver ikke denne å gjentas.

Magnus Løberg

magnus.loberg@medisin.uio.no

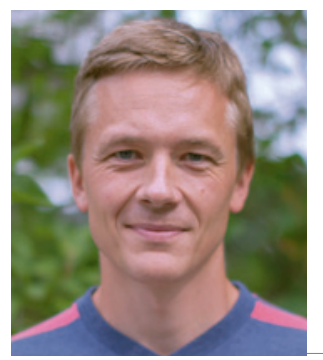

Magnus Løberg. Foto: Dagrunn Kyte Gjøstein

Disputas

Magnus Løberg disputerte for ph.d.-graden ved Universitetet i Oslo 20. januar 2015. Tittelen på avhandlingen er Prevention and early detection of colorectal cancer. A study of epidemiological methods to evaluate cancer screening and surveillance.

\section{Diabetes, diastolisk dysfunksjon og kardiovaskulær sykdom}

\section{Asymptomatisk diastolisk dysfunksjon ved type 2-diabetes er vanskelig å behandle. Kardiovaskulær risikoklassifisering kan forbedres med interleukin-6 og aktivin A.}

Type 2-diabetes er assosiert med asymptomatisk diastolisk dysfunksjon som øker risikoen for å utvikle hjertesvikt. Hvorvidt behandling av blodtrykk, hyperglykemi og lipider påvirker risikoen for hjertesvikt ved type 2-diabetes er ikke avklart. Nye, enkle markører for risikobedømming trengs.

I mitt doktorgradsarbeid undersøkte vi hjertefunksjonen hos 100 pasienter med type 2-diabetes. De ble undersøkt med arbeids-EKG og ekkokardiografi, inkludert vevsdoppler, og vi sammenliknet resultatene med hjertefunksjonen hos 100 friske, tett matchede kontroller. Pasientene med diabetes ble så randomisert til to års sykehusbasert, multifaktoriell behandling med aspirin og streng regulering av blodsukker, blodtrykk og lipider, eller standard behandling hos fastlege. Etter to år ble hjerteundersøkelsene gjentatt. Vi undersøkte videre om nivået av nye risikomarkører, blant annet interleukin-6 (IL-6) og aktivin A, ved inklusjon var assosiert med fremtidig død og kardiovaskulære hendelser.

Pasientene med type 2-diabetes hadde økt forekomst av diastolisk dysfunksjon sammenliknet med kontrollgruppen. Det multifaktorielle behandlingsopplegget hadde ingen innvirkning på hjertefunksjonen, til tross for større bedring i $\mathrm{HbA}_{1 \mathrm{c}}$, kolesterol og arbeidskapasitet. Interleukin- 6 og aktivin A var uavhengig assosiert med, og bedret risikoklassifiseringen for, fremtidig død og kardiovaskulære hendelser.

Måling av nivåene av interleukin- 6 og aktivin A kan på sikt inngå i risikobedømmingen av individer med type 2-diabetes.

\section{Anne Pernille Ofstad}

annepernille@hotmail.com

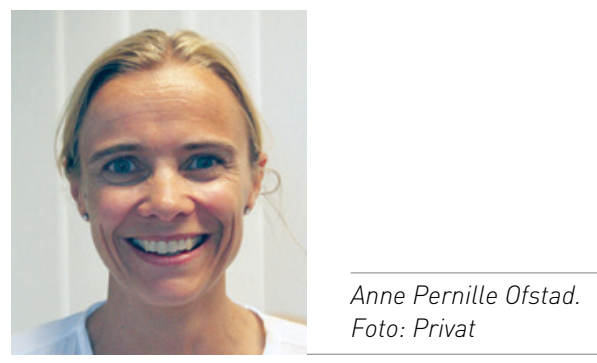

Disputas

Anne Pernille Ofstad disputerte for ph.d.graden ved Universitetet i Oslo 28. januar 2015. Tittelen på avhandlingen er Myocardial dysfunction and cardiovascular disease in type 2 diabetes. 